\title{
The Assesment of Capital Flow and Technology Transfer in Asparagus Production
}

\author{
Ni Nyoman Aryaningsih ${ }^{\mathrm{a}, *}$, I Ketut Irianto ${ }^{\mathrm{b}}$, \\ ${ }^{a}$ Accounting Department, Bali State of Polytechnic, Badung, Bali, 80361, Indonesia \\ ${ }^{b}$ Faculty of Agrotechnology Faculty, Warmadewa University, Denpasar, Bali, 80239, Indonesia \\ Corresponding author: "nyomanaryaningsih@pnb.ac.id
}

\begin{abstract}
The industrial sector has marginalized the agribusiness sector. The tight competition in the industrial sector has led to efforts by businesses to develop the agribusiness sector. The agribusiness sector has a vital role as state revenue and food security of rural households. Asparagus is one of the agribusiness commodities. Management of investment capital flows and technology transfer is an obstacle in improving the quality and quantity of asparagus production. Asparagus as a food crop commodity is sought after by the world community as a counterweight to food needs. This study aims to identify and analyze the development of Asparagus cultivation, investment capital flows, and technology transfer in asparagus production. The analytical method used is the assessment of investment capital flows and comparative studies. The research findings show that asparagus production is influenced by integrated development, capital flows, investment value, and technology transfer. The results of the analysis and assessment of investment capital flows, technology transfer show net B/C 1.01-2.21, IRR 24-35.87\%, payback period 3.7-4.0-month, maximum production life of 10 years. The maximum production value of 1 Ha of land is IDR 108,000,000/year; costs are IDR 68,800,000/year. The research findings show that (1) the ability to supply asparagus and the fulfillment of market needs tend to be unbalanced; (2) asparagus producers have a comparative advantage due to production technology.
\end{abstract}

Keywords - Technology transfer; money investment; technology transformation; food commodity; asparagus production.

Manuscript received 17 Mar. 2020; revised 7 Nov. 2020; accepted 24 Dec. 2020. Date of publication 28 Feb. 2021. IJASEIT is licensed under a Creative Commons Attribution-Share Alike 4.0 International License.

\section{INTRODUCTION}

The industrial sector has marginalized the agribusiness sector. The tight competition in the industrial sector between developed and developing countries has led to business players' efforts to shift their function to develop the agribusiness sector. The agribusiness sector has a vital role as a source of state revenue and food security for rural households. Four subsector groups as household food security sources include vegetables, fruits, ornamental plants, and bio-pharma or medicinal plants [1], [2]. Asparagus is one of the agribusiness commodities of the vegetable group. In the 1980-2000 period, the value of vegetable and fruit exports amounted to $12 \%$, increasing to $17 \%$. Asparagus is one of the food crop commodities in the world community as a counterweight to the middle class's food needs and above. In terms of market demand, the demand for asparagus commodities has increased in quality and quantity. However, the quality of the asparagus commodity has not been fulfilled for the global market's needs.
Global competition for asparagus producers is robust [3]. The use of water for asparagus cultivation is very inefficient, causing excessive water resource exploitation [4], [5]. Water as a community needs about $70 \%$ of the human body. Asparagus growing season in Peru causes loss of the welfare of asparagus producers around 64\% [6]. Asparagus is classified as a type of vegetable that is easily damaged due to weather changes. Very high import demand causes losses for other producing countries. This condition is an opportunity for asparagus producing countries with different climates. Asparagus has a very high added value as an antioxidant and automimic drug [1].

Therefore, asparagus is a source of human health. However, asparagus is a perishable plant different from the other product, so it is necessary to conserve asparagus plants. Besides, asparagus can grow for years up to 12-15 years or more. However, the optimal age for shoot production is 2-3 years, after which production will decline. The length of the asparagus stem is $18 \mathrm{~cm}-25 \mathrm{~cm}$. Peru has controlled asparagus's largest producer, while Asparagus's most significant demand in Germany, France, the United States 
[6]. Although the United States was initially an Asparagus importer, with changes in international trade policy, foreign competition, labor and Asparagus's scarcity caused the country to play the role of Asparagus producer by increasing technology transfer and labor costs [7].

Based on empirical studies conducted in the preliminary study, data and information were obtained that the number of Asparagus farmers in Pelaga village was around 200 people with an area of about 30 hectares. The average area of Asparagus land managed by farmers is around 15 acres. The average value of Asparagus cash flow per $1 \mathrm{Ha}$ is IDR $108,000,000 /$ year. These results are sold to the Mertanadi Cooperative without secondary processing. Average payback period of 3.7 years, Net B/C of 2.21, IRR obtained $35.87 \%$ [8], [9]. Net Present Value obtained amounted to $4,338,659$ with a risk level (discount factor) of 35\% [10], [11]. In 1999 Green Asparagus Production on California's $22 \mathrm{Ha}$ land reached $70 \%$ and White asparagus production at $30 \%$ [12]. Asparagus production in $18 \mathrm{Ha}$ land in Peru can currently produce $70 \%$ of green asparagus and $30 \%$ of white asparagus. Fresh asparagus is exported $60 \%$, canned Asparagus is exported $34 \%$, and frozen asparagus is exported $6 \%$.

Land conditions in Peru are unique: sandy soil, no rain, not too hot, and not too high climate. The use of production technology is a priority for asparagus producers. Asparagus in the tropics has a longer harvest period than non-tropical regions, so asparagus in the tropics provides a higher yield opportunity [13]. Production technology includes improved irrigation using drip irrigation, better nutrition, adequate crop density, integrated pest management, harvest throughout the year, developing crop management and production sites, better agricultural practices. The yield of asparagus quality is determined by the application of appropriate technology [13]. Asparagus from Peru has good quality because the farmers where technology adoption is carried out and leads to good market competitiveness.

Finally, Asparagus from Peru obtained a Copyright that was recognized in Europe and the United States. Thus, technology transfer can increase asparagus production and land use efficiency [14], [15]. Post-harvest technology can also choose a quality asparagus harvest, which has led to the use of labor being replaced by technology. Assessment of investment capital flows economically has a significant effect on the value of production [7], [16], [17].

Based on the results of empirical studies and reviews of previous research results, it can be concluded that the development, cultivation, and asparagus production influenced the carrying capacity of the land area by $98 \%$. Besides, market value is also determined by market changes such as demand, production cost, cost of capital, utility value, investment value, and technology transfer. The farmers of asparagus do not determine the standard cost. The study aimed to identify and analyze market supply and demand, assess the capital flow of investment, and technology transfer in asparagus production in Pelaga Village.

\section{Materials AND MethoD}

The study's object was conducted to examine the development of asparagus cultivation in the tourism village of Plaga Badung Regency in the Province of Bali. Since 2010. The village has begun developing Asparagus plants beginning with the OVOP (One Village One Product) program in collaboration between the Ministry of Cooperatives and SMEs with ICDF (International Cooperation Development Fund) of Taiwan. The initial research was conducted in the survey on 12 April-24 April 2019. Field research and focus group discussions were conducted from 19 July to 13 September 2019. Data analysis was carried out from 18 October to 24 November 2019.

\section{A. Research Design}

The design of this research was carried out in three stages:

1) Development of the Cultivation of Asparagus Plants: The development and cultivation of asparagus plants is an effort/process that has been planned and regulated in an integrated manner. The cultivation's planned steps begin with land management, nursery, planting, fertilizing, production, and production yields. Furthermore, farmers market the production of asparagus to form the selling price through the demands-supply market. The farming community as income to meet the community's living needs can use the sale of asparagus.

2) Investment Capital Flows: The investment capital flow is related to the amount of money invested from starting costs of processing land, seed costs, fertilizer costs, production costs to the production of asparagus have a market value with a risk level (discount factor).

3) Technology Transfer: Technology transfer is related to innovations made to increase production output from conventional to industrialization. Innovations are carried out, starting from the cost of innovation in the process of nursery treatment, planting, fertilizing, and achieving the results of production.

\section{B. Data Collections Methods}

Surveys, interviews, and focus group discussions can do data collection methods. The survey was conducted to obtain preliminary data on the number of Asparagus requests and offers. Interviews were conducted to obtain an overview of the development of asparagus production per day, the value of capital flows, and investments that farmer groups have carried out. Focus Group Discussions are conducted to obtain a picture of production by utilizing technology so that the ability to meet market needs can be formulated in the production technology system model.

1) Asparagus Cultivation Development: The development of Asparagus culture is carried out by identifying production and analysis characteristics between supply-demand and market needs employing a curve analysis [18].

2) The capital flow of investment: Investment capital flow analysis is done by analyzing the internal rate of return (IRR), net benefit/cost, and payback period [19], [20].

3) Technology Transfer Analysis: Technology transfer analysis is carried out using the biosystem and cold storage methods, which are testing the stages of the process and the treatment given [21]-[23]. 


\section{RESULTS AND DISCUSSION}

\section{A. Asparagus Cultivation Development}

Based on the analysis results, the capital flow of investment and technological transfer influences the development of asparagus cultivation. Asparagus Production without transferring technology can be shown in Table 1 .

TABLE I

Average of Green Asparagus Production in Pelaga Village

\begin{tabular}{lllll}
\hline \multirow{3}{*}{ Grade } & \multicolumn{4}{l}{ Characteristics of Production) } \\
& $\begin{array}{l}\text { Weight } \\
(\mathrm{g} / \mathrm{p})\end{array}$ & $\begin{array}{l}\text { Long } \\
(\mathrm{cm})\end{array}$ & $\begin{array}{l}\text { Price } \\
(\mathrm{IDR} / \mathrm{kg})\end{array}$ & $\begin{array}{l}\text { Production } \\
(\mathrm{kg} / \text { day })\end{array}$ \\
\hline Grade A & 0.48 & 21 & 80.000 & 12.5 \\
Grade B & 0.38 & 20 & 70.000 & 11.5 \\
Grade C & 0.33 & 19 & 60.000 & 10.5 \\
\hline
\end{tabular}

Based on the analysis of the calculation of production results, the market demand that can be met is an average of $37 \%$. The average number of asparagus $12 \mathrm{~kg} / \mathrm{hr}$. Other researchers' findings stated an average requirement that can be met by $38 \%$, and an average number of asparagus that can be met can be provided as much as $23 \mathrm{~kg} / 2$ days or $12.5 \mathrm{~kg} /$ day.

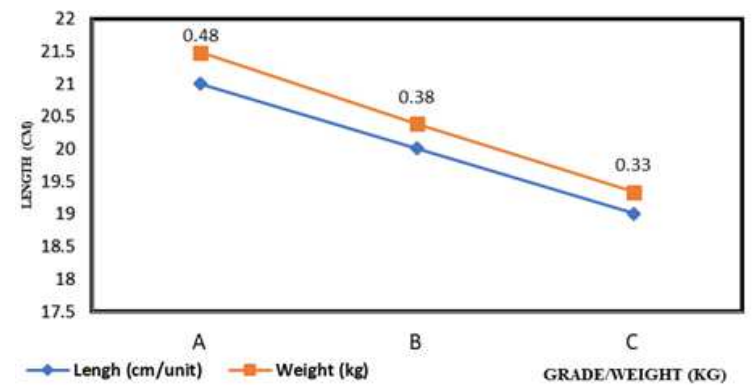

Fig.1 Graph and quality of asparagus production

Figure 1 shows that asparagus is classified base on grade (A, B, C), weight, and length. Grade A has length $0.48 \mathrm{~cm}$, B $0.38 \mathrm{~cm}, \mathrm{C} 0.33 \mathrm{~cm}$. Asparagus is a grade shown below.

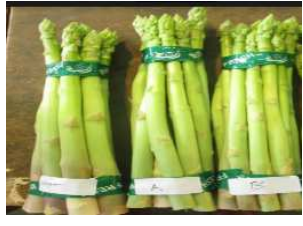

Grade A

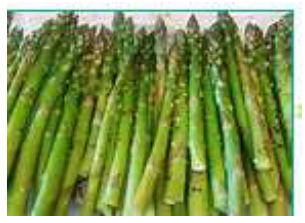

Grade B

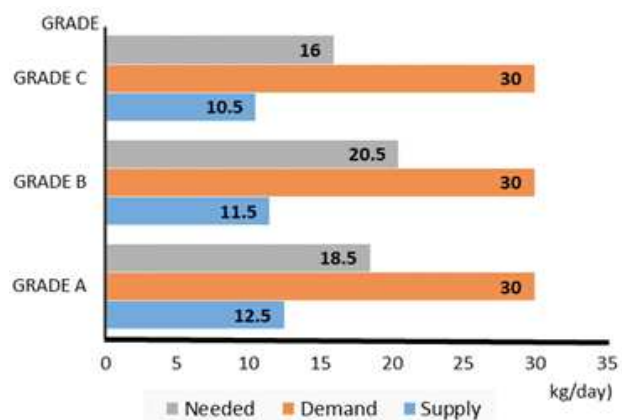

Fig. 2a Value of asparagus production based on demand and supply

Based on asparagus Grade, there is a change in demand for asparagus prices that tend to be elastic, and this means that changes in the market price of asparagus are not necessarily offset by an increase in changes in the amount demanded by consumers. The amount requested is almost no significant change, as shown in Fig. $2 \mathrm{a}$ and Fig. $2 \mathrm{~b}$.

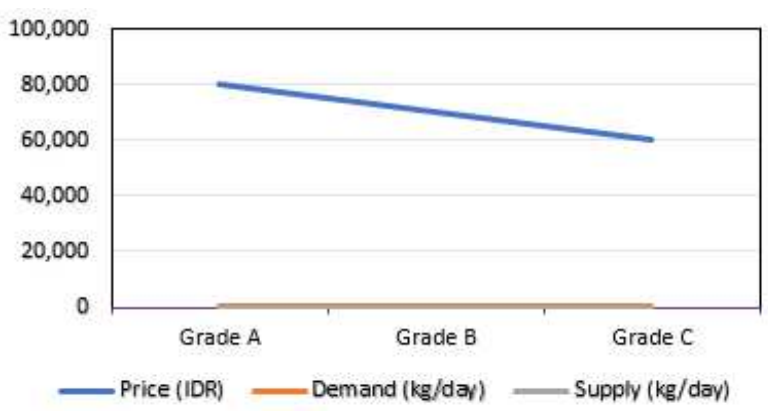

Fig 2b. Asparagus Demand Curve

Fig. $2 \mathrm{a}$ and $2 \mathrm{~b}$ show the changes in demand and supply market asparagus. Changes in Asparagus market demand are classified as elastic, as indicated by the curve's sloping inclination. This inclination means that the potential to supply asparagus to meet market needs is very high. Besides, asparagus market price changes are increasing because the asparagus harvest period in the tropics is longer compared to non-tropical regions. The demand for Grade an Asparagus is the highest compared to Grade B, and Grade C. Asparagus Grade A has the characteristics of straighter and bigger stems so that the stems are suitable for use in food [13] or bio-Pharmacia (medicinal material) [1]. Based on the analysis of market demand and supply shows that asparagus commodity needs are shown in Table 2.

TABLE II

Supply and DEMAND ASPARAGUS In PELAGa Village

\begin{tabular}{llll}
\hline Grade & $\begin{array}{l}\text { Supply } \\
\text { (kg/day) }\end{array}$ & $\begin{array}{l}\text { Demand } \\
\text { (kg/day) }\end{array}$ & $\begin{array}{l}\text { Needed } \\
\text { (kg/day) }\end{array}$ \\
\hline Grade A & 12.5 & 30 & 18.5 \\
Grade B & 11.5 & 30 & 20.5 \\
Grade C & 10.5 & 30 & 16 \\
\hline
\end{tabular}

Table 2 shows that there is an imbalance between asparagus's supply and demand and the fulfilment of market needs. The ability to meet Asparagus's market needs averages $67 \%$, so that the potential and supply opportunities of Asparagus are around 33\%.

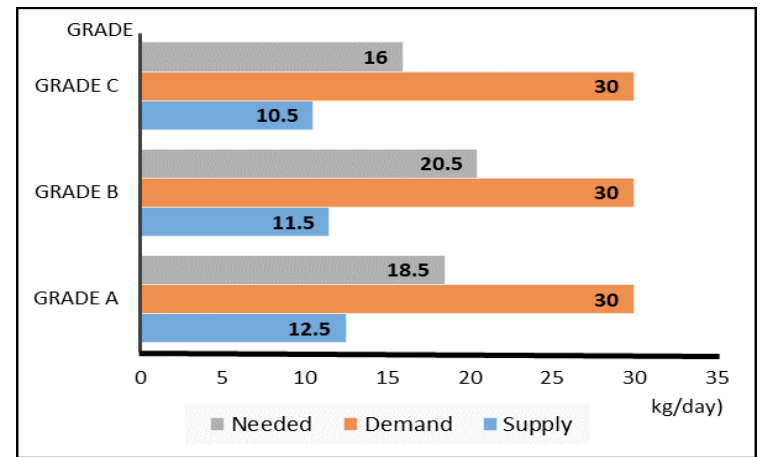

Fig. 3 Comparative of Asparagus Supply-Demand

Thus, it is necessary to use inputs and increase capital flows, including increasing land area, skilled labor, 
supplying seeds, production input (medicines), and technology transfer (production innovation). A comparison between supply-demand and Asparagus market needs can be shown in Fig. 3.

Figure 3 shows that the link between supply-demand asparagus and the highest-Grade B asparagus market needs has not been fulfilled according to the market demand of $37 \%$. Asparagus from consumers' perception of organic food is preferred for human health [18], [24]. Therefore, asparagus has become an international market trend. However, the availability of asparagus for market needs has not been able to be met by asparagus producers. A comparison between the ability to supply asparagus with the consumer market's needs tends to the low level of farmer groups to provide the amount of asparagus, as shown in Fig. 4.

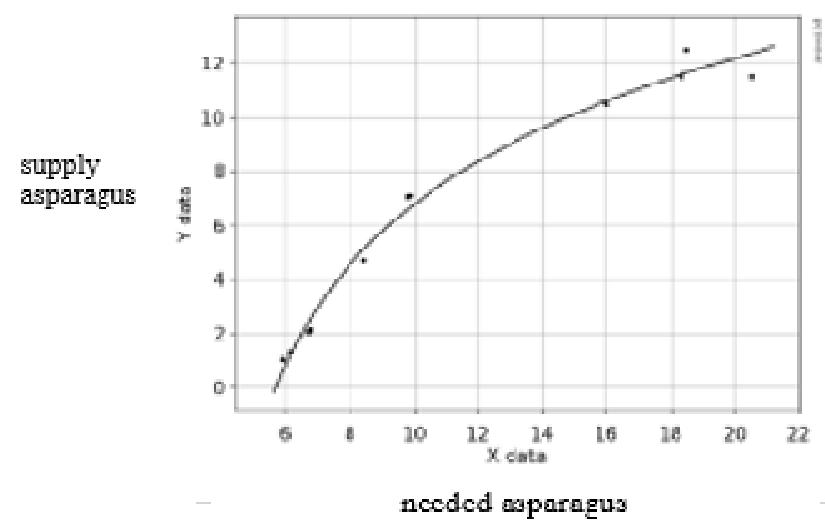

Fig. 4 Supply and Needed Comparative, Processed by zuzun.com

Fig. 4 shows an asparagus supply curve that tends to be non-linear. This non-linear curve means that the increased market demand for asparagus is not yet comparable to the asparagus farmers group's production capabilities to supply market needs. Production technology of transformation strategy is pursued through the efficiency of the production process and product quality to meet the market needs' production standards. This case is confirmed by the findings [25], [26].

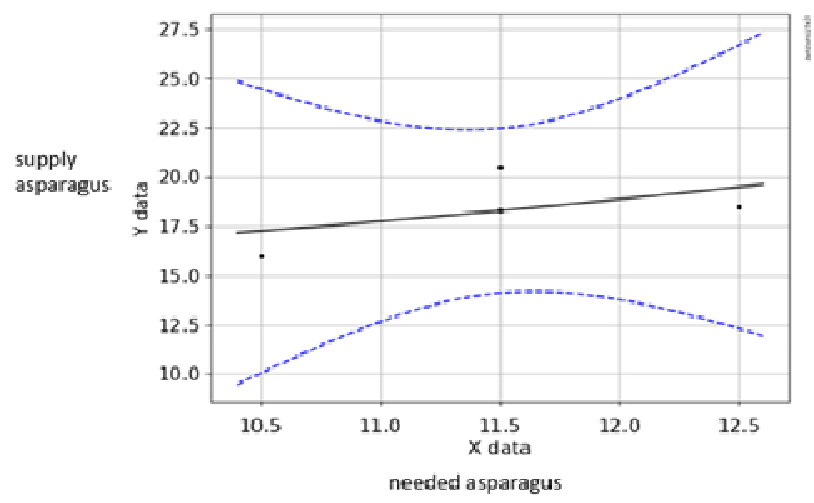

Fig. 5 Unbalanced Supply and needed Asparagus, Processed by zuzun.com

The unbalanced production asparagus supply with needed can be tested by $\mathrm{Y}$ data vs $\mathrm{X}$ data model, $\mathrm{y}=\mathrm{ax}+$ Offset, shown in Figure 5. Fig. 5 shows an imbalance between production supply (in the form of hyperbola) and fulfillment of market needs (in the form of a parabola) to reach the optimal line (line regression). It means that the addition of production supply will be followed by meeting the needs of market demand. However, this has not yet happened. The imbalance of supply and the fulfillment of asparagus market needs are caused by farmers' inability to get a complete information network, market search strategies, ease of market entry, and protection of government regulations [24], [27]. Therefore, that business actor needs to help the farmer that production asparagus gave them to consider peer advisors, and training entrepreneur use of social media for marketing.

\section{B. Investment Capital Flows Analysis}

Based on the results of the analysis, it was found that from 200 farmers, the total area of asparagus that farmers can manage is around 15 acres. The average investment value includes land investment, fertilizer, seed making, direct labor wages, post-harvest technology (cold storage), electricity, and water. The average investment value per are/year is IDR 688,000 . The average production cost is IDR 391,000/year. The average value of Asparagus cash flow per one Ha is IDR 108,000,000/year. Production results are sold to the Mertanadi Cooperative without secondary processing.

Furthermore, the Cooperative distributes Asparagus production to suppliers and foreign markets. Average payback period of 3.7 years, Net B/C of 1.01-2.21, [28], Internal Rate of Return (IRR) is obtained at $35.87 \%$, while IRR was $26.75 \%$ [23]. The expected cash value to be received is calculated based on the present value. Net Present Value is obtained at IDR 4,338,659 with a risk factor (discount factor) of $35 \%$ per year.

Asparagus's estimated production cost was reported from [29] that the costs incurred in the first $\$ 1000$ a year for land per acre. These costs include soil preparation for planting $\$ 40$, the asparagus crowns $\$ 360$, fertilizer (N-P-K) $\$ 60$, planting labor $\$ 80$, cultivating and hand hoeing $\$ 70$, fungicides and insecticides $\$ 50$, irrigation $\$ 60$, other costs (labor, land, interest, machinery) $\$ 280$. Research findings [30] that seasonal labor costs $30-60 \%$ of total production costs. Compared to the cost of producing asparagus between Indonesia (Pelaga Village) and Oklahoma, the cost of producing green asparagus per acre/year is IDR 688,000 (equal \$46). This number means a market opportunity for asparagus Pelaga Village farmers because production costs are lower so that it has the potential to compete and broader market access. Research findings [31] asparagus market has increased from $62 \%$ to $78 \%$ over four years (2005-2009). On the other hand, asparagus is a perishable, weak, insectprone plant, the money loss caused by a failure of asparagus production is around 20\%.[32]. Thus, asparagus farmers should have sufficient knowledge, techniques, and technology when focusing on cultivating asparagus, because asparagus is consumed by humans and has economic value as a medicinal ingredient [33]. Changes in international market conditions can also affect the competitiveness and prices of global asparagus. Factors affecting changes in international markets, such as industrial development, crop yields are determined by climate and soil conditions, the introduction of drip irrigation systems, integration of production and exports[6]. 
Parameters of the aggregate change in the production function are also determined by technology, productivity, and labor changes. Asparagus production's income/investment value can be measured by the number of results in units (\%), payback period, and benefit-cost. Comparison of investment yield and value can be measured by the IRR method, payback period, and Net B/C shown in Table 3.

TABLE III

COMPARATIVE INVESTMENT VALUE

\begin{tabular}{lll}
\hline $\begin{array}{l}\text { Investment value } \\
\text { Methods }\end{array}$ & Regional (\%) & $\begin{array}{l}\text { International } \\
(\%)\end{array}$ \\
\hline $\begin{array}{l}\text { Internal Rate of Return } \\
\text { (IRR) }\end{array}$ & 35 & 24 \\
Payback Period & 3.7 & \\
Net B/C & $1.01-2.21$ & $1.48-1.65$ \\
\hline
\end{tabular}

Table 3 shows the comparison of investment values measured from three methods, namely: Internal rate of return $>12 \%$ (ability to produce total production), outstanding, optimal payback period $>2-3$ years (harvest/production period) shows less optimal ability. Net Benefit/Cost $>1$ indicates that the investment feasibility is very feasible. The precise calculation of investment capital flows (financial) can significantly determine the factor cost of production [17]. Table 3 shows that the IRR above is supported by another study showing a $70 \%$ gross margin and an IRR of $25.5 \%$ [22]. The investment cost between asparagus required an investment value of 4.54 times higher than other plants [4]. Therefore, the contribution of asparagus profits was $56.3 \%$. This finding is reinforced [9] that investment costs on production results require differential sensitivity analysis to recognize the future value.

The normality of the production level of asparagus compared between regional and international regions measured by IRR, Payback period, and Net B/Cost shows the distribution of the von Mises model as in Fig. 6. The investment value measured by asparagus production capacity in less than four years shows a healthy change compared to regional and international production capacity when using technology transfer. The results of the statement are shown in Fig. 6.

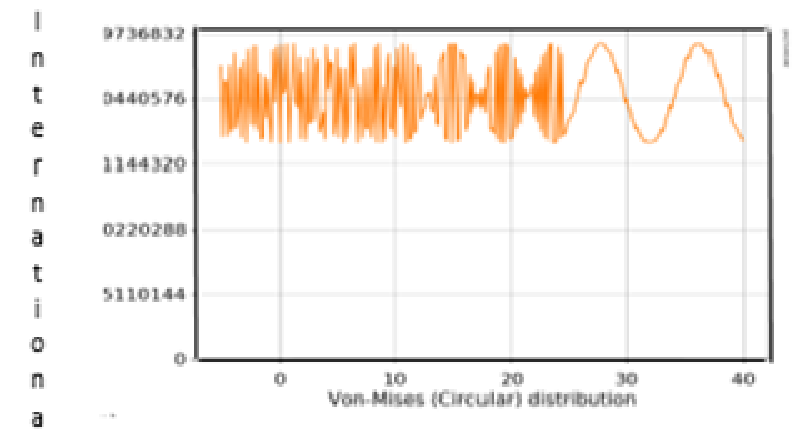

Regional

Fig. 6 Fluctuation of Value Investment on Asparagus Production

Fig. 6 shows that a combination of investment value analysis such as IRR, payback period, and net benefit/cost with a von Mises graph model is essential for business. The model is reinforced by the findings [34], [35] that in making investment decisions, it is necessary to calculate combinations and economic considerations [36]. The distribution von Mises show with the increasing payback period and the maximum Von Mises stress of the casing increases firstly and after the peak value [37]

TABLE IV

USING OF LAND AREA AND ASPARAGUS PRODUCTION

\begin{tabular}{llll}
\hline Country & $\begin{array}{l}\text { Land Area } \\
(\mathrm{Ha})\end{array}$ & $\begin{array}{l}\text { Green } \\
\text { Asparagus (\%) }\end{array}$ & $\begin{array}{l}\text { White } \\
\text { Asparagus (\%) }\end{array}$ \\
\hline Indonesia & 30 & 35 & 0 \\
US & 22 & 70 & 30 \\
(California) & & & \\
Peru & 18 & 70 & 30 \\
\hline
\end{tabular}

Table 4 shows the comparison of the value of land investment used to produce Asparagus between the three country of Indonesia, US (California), and Peru. Indonesia has the most extensive land use but the lowest production capability, [18], asparagus production is considered less efficient. The least amount of land used by Peru; green Asparagus production is almost the same as the State with a larger land area. This result means that the State of Peru has a comparative advantage in Asparagus production strengthened by the findings [13], [38]. A comparative advantage in technology-based production can create production efficiency [39], [40].

\section{Technology Transfer Analysis}

Based on observations of technology transfer using the trios monitoring system method, it shows that the technology used is through the stages of the process and safe treatment, efficient and environmentally friendly. Safe means not to use chemicals. Efficient means that the material used is relatively cheap and easy to obtain. Environmentally friendly means that the technology used does not cause damage to the ecosystem and the environment.

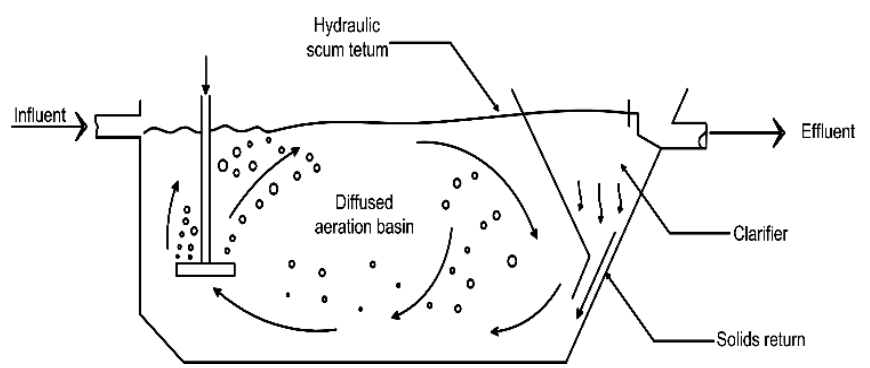

Fig. 7 Technology Transfer for production processing

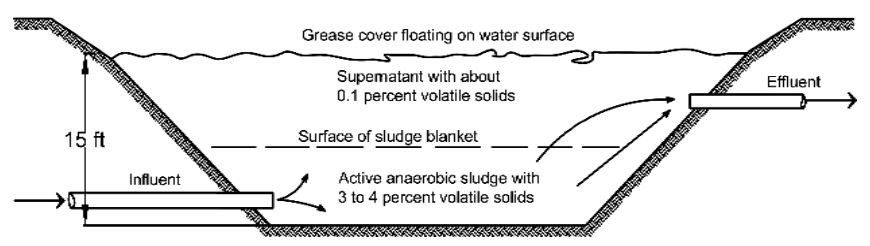

Fig. 8 Technology Transfer with fermentation

The technology transfer model using the biosystem method used is shown in Figure 1 and Figure 2. Figures 7 and 8 show the transfer of technology with biological 
principles by providing a $p H$ regulation of $6-7$, a temperature of $26-28^{\circ} \mathrm{C}$ at each stage of the microorganism bioactivity process can occur. The use of biosystem technology and cold storage can increase the quantity and quality of asparagus. This research found that storing asparagus at low temperatures can maintain asparagus quality as the most effective method [16], [19]. Other researchers found that techno-economic can increase gross margin by $70 \%$ and IRR by $25.5 \%$ [15], [23].

\section{CONCLUSION}

The results showed demand and supply market, the capital flow of investment and technology transfer, influenced by natural factors (land area) and the geophysical environment, information networking, and marketing, determined the development of asparagus production. The quality and quantity of asparagus are influenced by using technology with standardized treatment. Through regulation of $\mathrm{pH}$ 6-7 and temperature, $26-28^{\circ} \mathrm{C}$ can increase the bioactivity of microorganisms in organic fertilizer manufacture. The quality of asparagus is influenced by the $\mathrm{pH}$ and temperature control of $1-2^{\circ} \mathrm{C}$ in cold storage technology as the most effective method.

Aside from being influenced by nature and geographical environment, asparagus is also determined by integrated development, capital flows, investment value, and production technology. The results of the analysis and assessment of investment capital flows, technology transfer, shows net B/C 1.01-2.21, IRR 24-35.87\%, payback period 3.7-4.0, maximum production life of 10 years. The maximum production value of $1 \mathrm{Ha}$ of land is IDR $108,000,000$ /year; production costs are IDR 68,800,000/year. There are differences in the number and quality of production between countries due to production technology. The imbalance of supply and the fulfillment of asparagus market needs are caused by farmers' inability to get a complete information network, market search strategies, ease of market entry, and protection of government regulations. The recommendation of this research results requires further study on investment analysis and the comparative advantages of production based on similar technology between some countries.

\section{ACKNOWLEDGMENT}

We are grateful to the publishers, reviewers, and higher education institutions who have provided a forum for sharing research results that can be used as a reference and provide benefits of the knowledge development for productive generations.

\section{REFERENCES}

[1] N. Bopana and S. Saxena, "In vitro propagation of a high value medicinal plant: Asparagus racemosus Willd.," Vitr. Cell. Dev. Biol. - Plant, 2008

[2] I. K. Irianto and G. Y. Arygunartha, "Evaluating food waste handling using trios monitoring system on soy industry in Bali, Indonesia," Int. J. Adv. Sci. Eng. Inf. Technol., 2019.

[3] J. Ziegler and W. Riedel, "Asparagus cultivation in Peru.," Gemüse (München), 2000.

[4] J. L. R. Flores et al., "Analysis of physical, economic and social water efficiency in asparagus (Asparagus officinalis L.) and grape
(Vitis vinifera) fruit from DR-037 of Altar-Pitiquito-Caborca, Sonora, Mexico 2014," Rev. la Fac. Ciencias Agrar., 2018.

[5] I. G. A. P. Eryani and I. K. Irianto, "Water Management Of River Estuary For The Preparation Of Ecotourism In Coastal Area Of Bali Province," Int. J. Appl. Sci. Tour. Events, 2018.

[6] T. Shimizu, "Expansion of Asparagus Production and Exports in Peru," Discuss. Pap., 2006.

[7] C. D. Clary et al., "Performance and economic analysis of a selective asparagus harvester," Appl. Eng. Agric., 2007.

[8] P. Campi, M. Mastrorilli, A. M. Stellacci, F. Modugno, and A. D. Palumbo, "Increasing the effective use of water in green asparagus through deficit irrigation strategies," Agric. Water Manag., 2019.

[9] M. Percoco and E. Borgonovo, "A note on the sensitivity analysis of the internal rate of return," International Journal of Production Economics. 2012.

[10] M. L. Makosholo and A. Jooste, "The comparative advantage of selected long-term crops in Lesotho," Agrekon, 2006.

[11] T. A. Weber, "On the (non-)equivalence of IRR and NPV," J. Math. Econ., 2014.

[12] A. Casas and J. Sanchez, "Developments in asparagus cultivation under desert conditions in peru," in Acta Horticulturae, 2008.

[13] P. Dalampakis, J. Gelegenis, A. Ilias, A. Ladas, and P. Kolios, "Technical and economic assessment of geothermal soil heating systems in row covered protected crops: A case study from Greece," Appl. Energy, 2017.

[14] N. Irie, N. Taguchi, T. Horie, and T. Ishimatsu, "Asparagus harvesting robot coordinated with 3-D vision sensor," in Proceedings of the IEEE International Conference on Industrial Technology, 2009.

[15] H. S. Yoon and H. M. Kang, "Influence of pretreatments and modified atmosphere packaging on toughness and quality of asparagus spears during storage," Korean J. Hortic. Sci. Technol., 2017.

[16] S. Ogilvy and M. Vail, "Standards-compliant accounting valuations of ecosystems," Sustain. Accounting, Manag. Policy J., 2018.

[17] B. Iráizoz, M. Rapún, and I. Zabaleta, "Assessing the technical efficiency of horticultural production in Navarra, Spain," Agric. Syst., 2003.

[18] W. M. Lim, J. L. S. Yong, and K. Suryadi, “Consumers' Perceived Value and Willingness to Purchase Organic Food," J. Glob. Mark., 2014.

[19] S. Harding, T. Long, S. Harding, and T. Long, "Internal rate of return (IRR)," in MBA Management Models, 2018.

[20] M. Santandrea, A. Sironi, L. Grassi, and M. Giorgino, "Concentration risk and internal rate of return: Evidence from the infrastructure equity market," Int. J. Proj. Manag., 2017.

[21] I. J. Petrick and A. E. Echols, "Technology roadmapping in review: A tool for making sustainable new product development decisions,' Technol. Forecast. Soc. Change, 2004.

[22] D. Gómez-Ríos, R. Barrera-Zapata, and R. Ríos-Estepa, "Comparison of process technologies for chitosan production from shrimp shell waste: A techno-economic approach using Aspen Plus ${ }^{\circledR}, "$ Food Bioprod. Process., 2017.

[23] W. Han, J. Fang, Z. Liu, and J. Tang, "Techno-economic evaluation of a combined bioprocess for fermentative hydrogen production from food waste," Bioresour. Technol., 2016.

[24] A. J. Culyer and K. Chalkidou, "Economic Evaluation for Health Investments En Route to Universal Health Coverage: Cost-Benefit Analysis or Cost-Effectiveness Analysis?," Value Heal., 2019.

[25] T. L. Tang and S. Motoki, "Differences in growth-inhibitory activity among different parts of asparagus and the effects of activated carbon on its reduction," Acta Hortic., 2018.

[26] I. Vazquez-Rowe, R. Kahhat, I. Quispe, and M. Bentín, "Environmental profile of green asparagus production in a hyper-arid zone in coastal Peru," J. Clean. Prod., 2016.

[27] A. Diamond, D. Tropp, J. Barham, M. F. Muldoon, S. Kiraly, and P. Cantrell, "Food Value Chains: Creating Shared Value to Enhance Marketing Success," U.S. Dept. Agric. Agric. Mark. Serv., 2014.

[28] G. Di Vita et al., "Can sustainability match quality citrus fruit growing production? An energy and economic balance of agricultural management models for 'PGI clementine of calabria,', Agron. Res., 2018.

[29] L. Brandenberger, J. Shrefler, and J. Damicone, "Asparagus Production," no. August, 2015.

[30] M. Schulte and L. Theuvsen, "Influence of incentive system design on individual farm performance: A survey in the German strawberry and asparagus sectors," Eur. J. Hortic. Sci., 2015. 
[31] B. L. Benson, "2009 update of the world's asparagus production areas, spear utilization and production periods," in Acta Horticulturae, 2012.

[32] F. H. Chittenden, The asparagus beetles /. 2013.

[33] F. H. Takatori, "Asparagus officinalis," in Handbook of Flowering: Volume I, 2018

[34] J. M. Herbener and D. J. Rapp, "Toward a subjective approach to investment appraisal in light of Austrian value theory," $Q . J$ Austrian Econ., 2016

[35] V. G. Kostenkova, "The Need For Implementation Of A Tight Monetary Policy As A Condition For Achieving Long-Term Economic Goals," Bull. Udmurt Univ. Ser. Econ. Law, 2019

[36] Y. Yan, B. Shao, X. Zhou, S. Song, X. Zhou, and X. Yan, “A study on the influence of double ellipsoidal pitting corrosion on the collapsing strength of the casing," Eng. Fail. Anal., 2019.
[37] Z. Fan, L. Xia, W. Lai, Q. Xia, and T. Shi, "Evolutionary topology optimization of continuum structures with stress constraints," Struct. Multidiscip. Optim., 2019.

[38] A. P. Chatzimichali, I. P. Georgilas, and V. D. Tourassis, "Design of an advanced prototype robot for white asparagus harvesting," in IEEE/ASME International Conference on Advanced Intelligent Mechatronics, AIM, 2009.

[39] X. Chen, C. Liu, and S. Li, "The role of supply chain finance in improving the competitive advantage of online retailing enterprises,' Electron. Commer. Res. Appl., 2019.

[40] S. Fainshmidt, L. Wenger, A. Pezeshkan, and M. R. Mallon, "When do Dynamic Capabilities Lead to Competitive Advantage? The Importance of Strategic Fit," J. Manag. Stud., 2019. 